
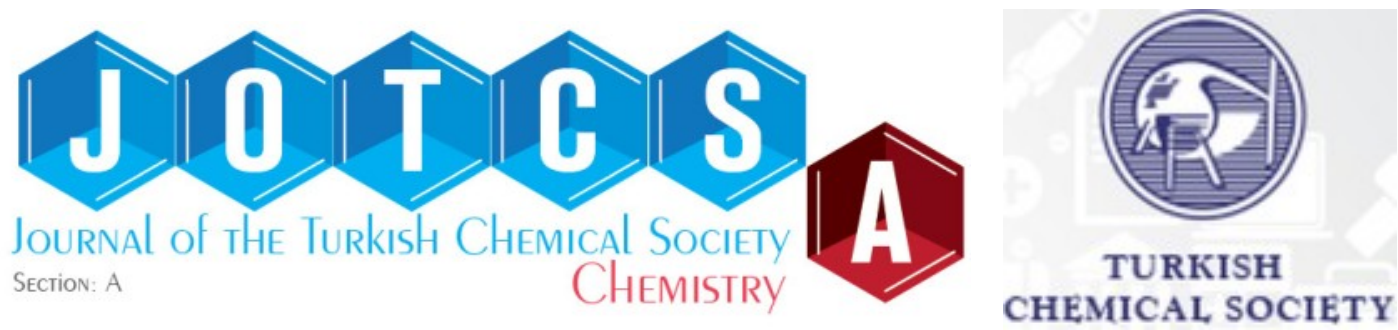

\title{
Bioassay-Guided Separation Approach for Characterization of New Antibacterial Fractions from the Stem Roots Extracts of Archidendron jiringa
}

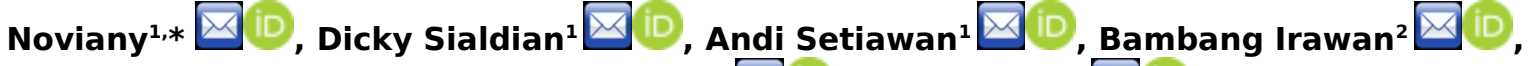 \\ Mohamad Nurul Azmi $\triangle D$, Sutopo Hadi
}

\author{
${ }^{1}$ Department of Chemistry, Faculty of Mathematics and Natural Sciences, University of Lampung, Bandar \\ Lampung 35145, Lampung, Indonesia \\ ${ }^{2}$ Department of Biology, Faculty of Mathematics and Natural Sciences, University of Lampung, Bandar \\ Lampung 35145, Lampung, Indonesia \\ ${ }^{3}$ School of Chemical Sciences, Universiti Sains Malaysia, Minden 11800, Penang, Malaysia
}

\begin{abstract}
Infectious diseases caused by bacteria has become a global health issue, especially antibacterial drug resistance. The most serious concern with antibacterial resistance is that some bacteria became resistant to almost all antibacterial drugs, which makes them less effective. Archidendron jiringa is one of the most potent medicinal plants to be developed as a new source of antibacterial components. In current study, based on the antibacterial assay-guided approach, the separation of bioactive fractions of $A$. jiringa stem roots was carried out through several stages including isolation, fractionation, and characterization. The stages of isolation of secondary metabolites were conducted by gradually extraction followed by fractionation using chromatographic methods. The antibacterial potential of extracts was evaluated by the disc diffusion and microdilution methods employing the resazurin assay against one Gram-negative resistant bacteria, Escherichia coli, and one Gram-positive bacteria, Bacillus subtilis. Among three extracts obtained, ethyl acetate and methanol extracts demonstrated to be the most significant antibacterial effects, while no antibacterial activity was shown on the n-hexane extract. The fractionation of ethyl acetate extract led to the isolation of the most bioactive fractions $\left(E_{2} 8_{1} 5\right.$ and $\left.E_{2} 8_{1} 6\right)$ with the MIC's values ranging of $12.5-25 \mu \mathrm{g} / \mathrm{mL}$ for both resistant bacteria. Due to the low amount, only the fraction $E_{2} 8_{1} 6$ was subjected to analysis by ${ }^{1} \mathrm{H}-\mathrm{NMR}$ spectroscopy. The results exhibited that the bioactive fraction was obtained as a mixture of at least three major constituents. However, the purification of the bioactive fraction is required, to further clarify the antibacterial compound that can be utilized as a new promising antibacterial agent. The bioassay-guided separation approach and the dye resazurin as an indicator of the growth of bacteria are applied for the first time for the phytopharmacological investigation from this plant. The present study represented the most effective method for subsequent finding and isolation of potential novel antibacterial constituents from $A$. jiringa stem roots, in particular against the multi-drug resistant strains.
\end{abstract}

Keywords: $A$. jiringa, antibacterial assay, bioassay-guided separation, medicinal plant

Submitted: November 25, 2020. Accepted: January 27, 2021.

Cite this: Noviany N, Sialdian D, Setiawan A, Irawan B, Azmi MN, Hadi S. Bioassay-Guided Separation Approach for Characterization of New Antibacterial Fractions from the Stem Roots Extracts of Archidendron jiringa. JOTCSA. 2021;8(2):391-402.

DOI: https://doi.org/10.18596/jotcsa.831054.

*Corresponding author. E-mail: NOVIANY@FMIPA.UNILA.AC.ID. 


\section{INTRODUCTION}

Infectious disease is a serious global health problem, and every year, it causes deaths of 13 million people worldwide, especially in developing countries like Indonesia $(1,2)$. WHO (World Health Organization) data show that viral, bacterial, fungal and parasitic infections are the biggest cause of death for the world's population. The use of antibiotics in the prevention of infectious diseases is the only solution (3). However, continuous use of antibiotics raises new problems for health, especially the resistance of microorganisms that causes infection $(1,2)$. Bacteria are the most abundant organisms and widespread in living things. In terms of distribution and number, most bacteria may cause disease in humans and other living things (3). B. subtilis and $E$. coli are the most common pathogenic bacteria in humans; $E$. coli is a Gram negative bacterium found in the large intestine of humans, and is a major cause of diarrheal diseases, especially in infants and children (1-3). The mortality rate from diarrhea in Indonesia is still around $7.4 \%$, while the mortality rate due to persistent diarrhea is higher at $45 \%$. In 1,000 inhabitants, 200-374 subjects experience diarrhea, with $60 \%-70 \%$ of whom are children under the age of $5(4)$.

Bacterial resistance to antibiotics is a problem that has not been resolved until now $(3,5,6)$. The $E$. coli resistants to chloramphenicol group of antibiotics and amoxicillin have long been reported $(2,3,7,8)$. The greater the percentage of bacterial resistance to an antibiotic state that bacteria are no longer susceptible to these antibiotics. Various studies to overcome the bacterial resistance were carried out, but no effective reports exist. Thus, investigating new antibacterial substances that are still active and selective is necessary. The search for antibiotic sources from natural ingredients is still the main trend for researchers. The ability of bioactive compounds of natural materials as a healing medium is estimated because of the content of secondary metabolites, including terpenoids, steroids, coumarin, flavonoids, and alkaloids (1018).

One of the plants that has not been studied intensively in Indonesia is the family of Fabaceae $(18,19)$. The Fabaceae family demonstrates quite interesting bioactivity such as antibacterial $(18,19)$, antituberculosis (20), antioxidants (21), anticancer $(22)$, and antimalarial $(18,23)$. The jengkol plant $(A$ jiringa (Jack) I. C. Nielsen), which belongs to the Fabaceae family, is commonly used by the Indonesian people as traditional medicine (18). Jengkol leaves are efficacious as medicine for eczema, scabies, sores, and ulcers, and the skin of the fruit is used as ulcerative medicine. Several studies were carried out on jengkol plants, including the leaves, fruit peel, and seeds $(18,19,21,24)$. The phytochemical screening has been done on jengkol fruit peel, seeds, bark, and leaves extracts (24). Based on this screening, from the parts of jengkol contain alkaloids, steroids, triterpenoids, glycosides, saponins, flavonoids, and tannins. However, research on the stem roots of the jengkol plant was never performed.

In our ongoing investigation for new lead constituents from medicinal plants, we elaborated the bioactive secondary metabolites of $A$. jiringa stem roots and assayed their antibacterial activity. The aims of the study were to obtain antibacterial active fractions from the stem roots of $A$. jiringa, based on the bioassay-guided separation approach through their antibacterial property.

\section{EXPERIMENTAL SECTION}

\section{Plant Materials}

Samples of the stem roots of $A$. jiringa were assembled on January 25, 2018 from Unila's Housing area at Gedongmeneng District, Bandar Lampung, Lampung Province, Indonesia. The plant specimens (NV6/NRGD/2018) were identified at the Herbarium Bogoriense, LIPI Bogor, Indonesia.

\section{General Experimental Procedures}

TLC was performed on silica gel $60 \mathrm{GF}_{254}$ plates (Merck; $0.25 \mathrm{~mm}$ ) and sprayed with staining reagen $\mathrm{Ce}\left(\mathrm{SO}_{4}\right)_{2}$. Column chromatography $(\mathrm{CC})$ was made on silica gel (Kieselgel 60, 70-230 mesh ASTM; Merck) and Sephadex LH-20. ${ }^{1} \mathrm{H}$ NMR spectrum was measured in acetone- $d_{6}$ (TMS as an internal standard), on an NMR Agilent $500 \mathrm{MHz}$ spectrophotometer (Agilent Technologies, JNMECZ500R/S1) or Bruker $500 \mathrm{MHz}$ spectrometer. Finally, Microplate Reader Hospitex-Italy was used to measure the absorbance resulted on the resazurin assay, while UV spectra were performed using an Eppendorf BioSpectrometer kinetic instrument.

\section{Bacterial Strains and Biochemicals}

Ampicillin and chloramphenicol were purchased from Sigma Aldrich, and resazurin sodium salt was purchased from Sigma Aldrich. Gram-positive bacteria, $B$. subtilis ITBCCB148, was obtained from the Microbiology and Fermentation Technology Laboratory, Bandung Institute of Technology, Gramnegative bacteria, $E$. coli UNIATCC25922, nutrient agar broth, disposable sterile petri dishes (Idealcare), disposable syringe, micropipette tips, sterile tissue culture 96-well plates.

\section{Preparation of Extracts}

Fresh chopped stem roots of $A$. jiringa $(2.5 \mathrm{~kg}$ ) were cleaned by rinsing under running tap water to remove soil and dirt. The samples were dried in an open space for three weeks, and the air-dried roots are finally ground into a powder form. The powdered air-dried stem roots $(1.5 \mathrm{~kg})$ were extracted with a polar gradient polarity of solvent using the maceration technique. The solvent used at this stage starts from the solvent which exhibits the lowest polarity, $n$-hexane, followed by ethyl acetate (EtOAc), and finally with a high polarity organic solvent, methanol. Each extraction was conducted three times in each type of solvent. Before changing the type of solvent, the extract residue is first air 
dried for at least three days or until the residue is dry/free of solvent. The filtrates obtained from maceration obtained from polar gradient solvents are then separated from the residue by ordinary filtration. The filtrates are then concentrated under reduced pressure using a vacuum rotary evaporator to yield $n$-hexane $(3.6 \mathrm{~kg})$, EtOAc $(55.8 \mathrm{~kg})$, and methanol $(67.2 \mathrm{~kg})$ extracts, respectively. Using agar disc diffusion and microdilution methods, each extract obtained was subjected to an assay of its antibacterial activity. The most active extract was further isolated and fractionated through the bioassay-guided separation approach. The general research flowchart can be seen in Figure 1.

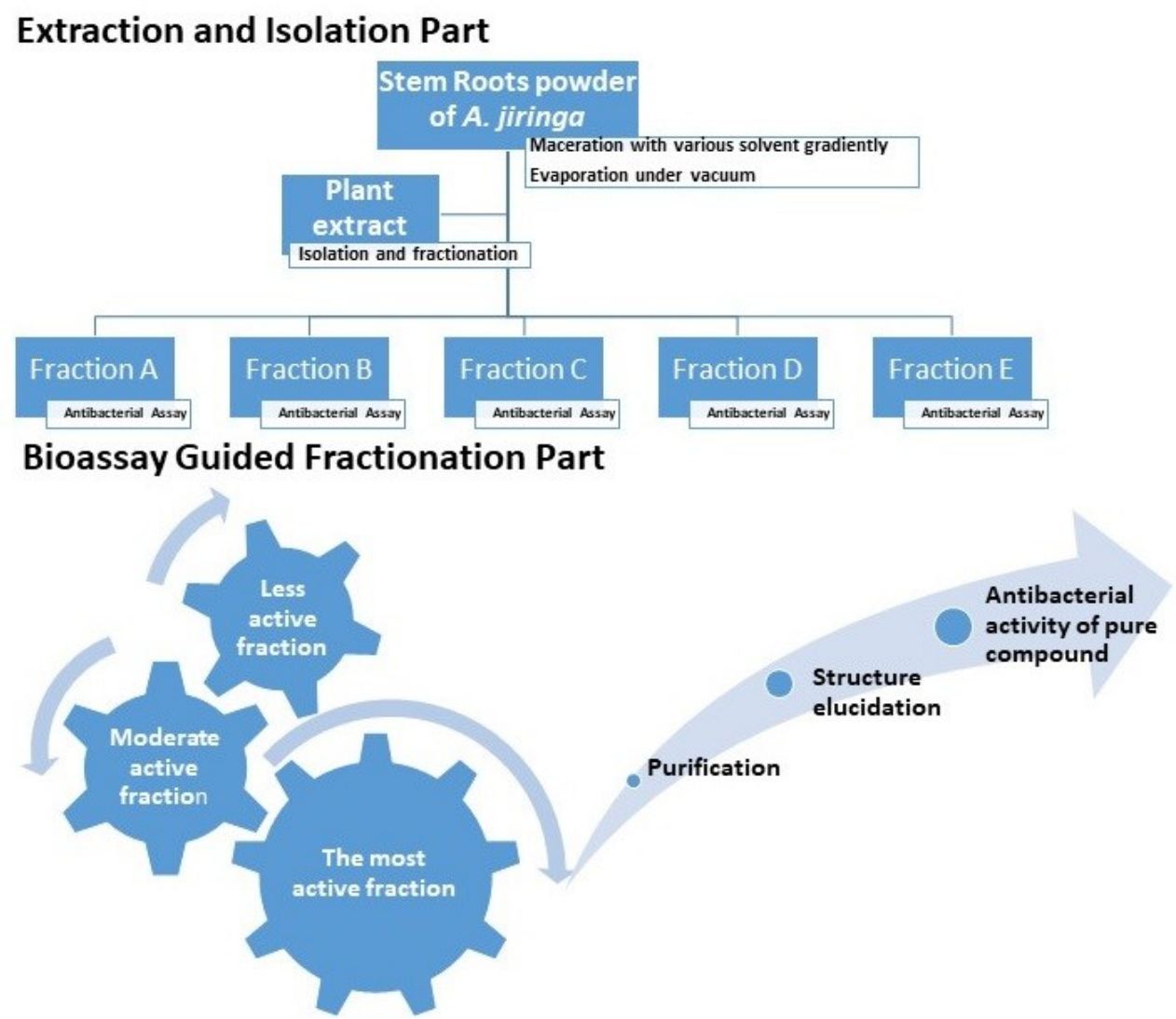

Figure 1. Research flow chart of bioassay guided separation.

Bioassay-guided Separation of Ethyl Acetate Extract

Based on the antibacterial activity results of extracts, the EtOAc extract $(55.8 \mathrm{~g})$ was selected to be isolated and fractionated further using the VLC method on silica gel (35-70 Mesh). The column was eluted with a stepwise gradient polarity of the solvent systems, including $n$-hexane-EtOAc $(100 \%$ $0 \%$ of $n$-hexane), EtOAc-acetone (100\%-0\% of EtOAc), and acetone-MeOH (100\%-0\% of acetone), affording 23 fractions ( $200 \mathrm{~mL}$ each). According to their chemicals profile analyzed by TLC and their proton NMR spectrum, these fractions were grouped and combined into seven primary fractions, $E_{2} 1$ (fr.1-10), $E_{2} 2$ (fr.11), $E_{2} 3$ (fr.12), $E_{2} 4$ (fr.13), $E_{2} 5$ (fr.14-15), $E_{2} 6$ (fr.16-19), $E_{2} 7$ (fr.20-23) (Figure 2). All fractions $E_{2} 1-E_{2} 7$ were tested for their antibacterial property separately using disc diffusion and microdilution methods. Among all fractions tested, three fractions exhibited antibacterial activity against both bacterial strains with quite similar MIC's values, therefore fraction $E_{2} 2$ (439.5 $\mathrm{mg}$ ) was subjected to further fraction due to the simplest chemical profile on its TLC. Fraction $E_{2} 2$ was redissolved in acetone and then purified with CC on silica gel G-60 (35-70 Mesh) using $n$-hexane/isopropyl alcohol with the ratio volumes of $70 / 30,60 / 40,50 / 50$, and 40/60, generating six major subfractions, $E_{2} 2 a(132.0 \mathrm{mg}), E_{2} 2 b(8.4 \mathrm{mg})$, $E_{2} 2 c(9.0 \mathrm{mg}), E_{2} 2 \mathrm{~d}(47.0 \mathrm{mg}), E_{2} 2 \mathrm{e}(2.0 \mathrm{mg})$, and $E_{2} 2 f(50.3 \mathrm{mg})$. Using microdilution methods, all subfractions were screened against both bacterial strains tested. The MIC's values and optical density (OD) means of bioactive subfractions were described on Table 2. Among them, two subfractions $\left(E_{2} 2 e\right.$ and $\left.E_{2} 2 f\right)$ performed the most antibacterial activity against $B$. subtilis and $E$. coli, with the MIC's values ranging of $12.5-25 \mu \mathrm{g} / \mathrm{mL}$. Only subfraction $\mathrm{E}_{2} 2 \mathrm{f}$ was selected to be analyzed further by ${ }^{1} \mathrm{H}-\mathrm{NMR}$ spectroscopy as exhibiting sufficient quantity. 


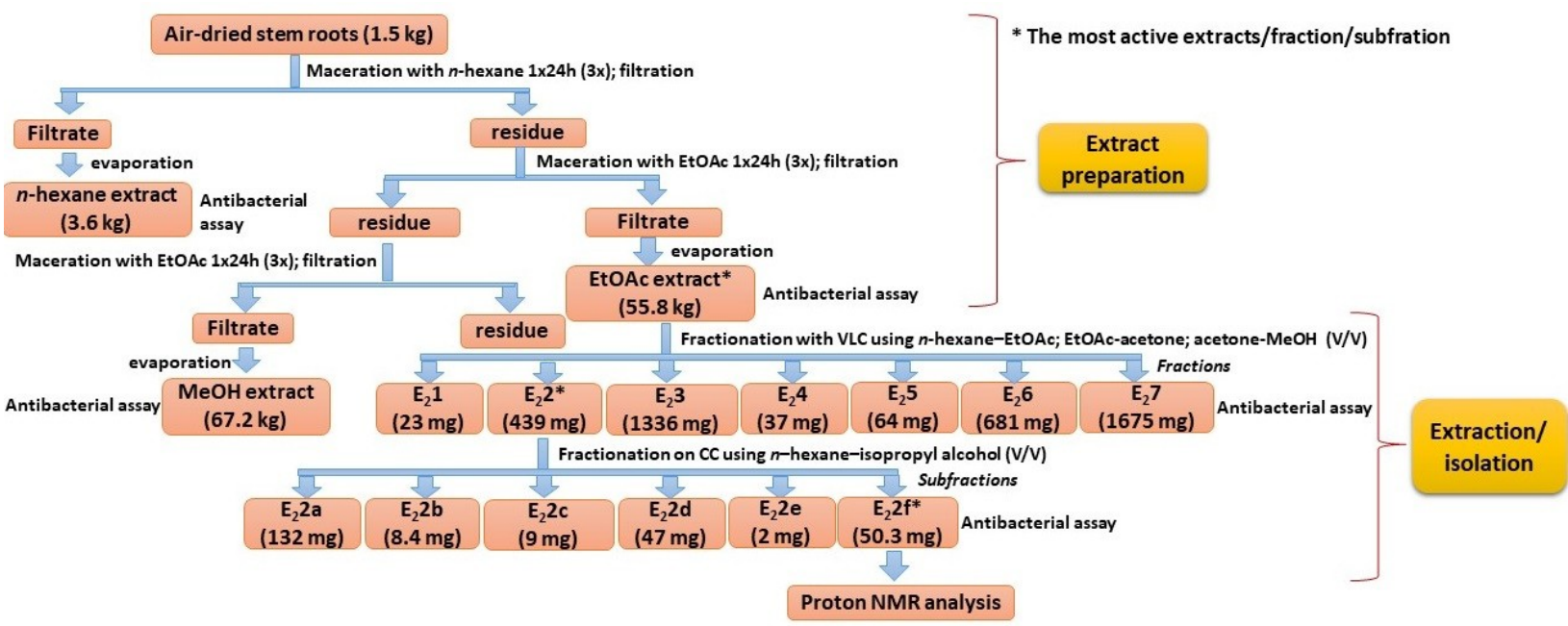

Figure 2. Scheme of bioassay guided separation of EtOAc extract subfractions.

\section{Phytochemical Screening}

The phytochemical screening was performed for triterpenes/steroids, alkaloids, flavonoids, and saponins, by using the standard procedures (25). The formation of precipitate or the color intensity was applied for analytical response of screening results.

\section{Evaluation of Antibacterial Activity}

For the testing antibacterial activity, the microbial strains employed in the biological assay are gram positive bacteria, Bacillus subtilis. Gram negative bacteria, Escherichia coli, have been obtained from a stock culture from Hospital Abdul Muluk, Bandar Lampung, Indonesia. To maintain stock culture, original cultures are further stored at a low temperature in the refrigerator. Fresh cultures are used for testing antibacterial activity using disc diffusion assay and dilution methods.

\section{Disc diffusion assay}

The antibacterial activity of the stem roots extract ( $n$-hexane, ethyl acetate, and methanol) were tested by the disc diffusion method (26) against pathogenic bacteria gram negative $(E$. coli) and gram positive (B. subtilis). In this method, freshly prepared agar media is dispensed into the sterilized petri-dish. The agar is allowed to solidify, and $100 \mu \mathrm{L}$ of the bacterial suspension was poured over the agar media and spread by a spreader or a rod. Ampicillin and chloramphenicol (30 $\mathrm{\mu g} / \mathrm{dish})$ is used as a positive control, while methanol is used as a negative control. In each culture medium petri-dish, four disks were used, one disk of antibiotics, two discs separately for ( $n$-hexane, ethyl acetate, and methanol) extracts, and one disk used as a control (methanol). The plates are sealed and incubated overnight at $37^{\circ} \mathrm{C}$ in the incubator. Next, antibacterial activity is assigned by measuring the inhibition zone formed around the discs, and the diameter of zone of inhibition (mean of three replicates SD) as indicated by clear area was measured to determine the antibacterial activity.
The experiment is replicated three times to confirm the reproducibility.

\section{Determination of MIC via Resazurin Assay}

Resazurin assay was carried out in 96-well plates titration with some minor modification (27). In the complete nutrient broth, two-fold dilutions of plant extracts and antibiotics were prepared in the test wells. The final concentration $(20 \mu \mathrm{L}$ of each bacterial suspension) was added to $180 \mu \mathrm{l}$ of antibiotics and plant extracts $(30-0.02 \mathrm{mg} / \mathrm{mL}$ in sequence) contained in the culture medium, as well as the antibiotics concentrations of $0.06 \mathrm{mg} / \mathrm{mL}$ and $0.12 \mathrm{mg} / \mathrm{mL}$ for amphicilin and chloramphenicol, respectively. For the comparative study, control plates were prepared only with the culture medium and bacterial suspension. The plates were sealed and incubated for 12 hours at $37^{\circ} \mathrm{C}$ for an additional 5 hours. At 1-hour intervals, plates were observed for a blue to pink and pink to colorless color change in living bacterial strains containing wells. Preliminary micro titer plate assay reveals that the fast decolonization of resazurin extract does not exhibit antibacterial potential. The bioactivity of extracts was screened, which shows that the extracts inhibit the dye reduction.

\section{RESULTS AND DISCUSSION}

The plant material was macerated using gradient polarity of solvent and afforded $n$-hexane $(3.6 \mathrm{~kg})$, EtOAc $(55.8 \mathrm{~kg})$, and methanol $(67.2 \mathrm{~kg})$ extracts. EtOAc extract performed the most bioactive extract against two bacterial strains, E. coli and B. subtilis, using agar disc diffusion and microdilution methods. Using the diffusion method, extracts of $n$-hexane, EtOAc, and methanol obtained from the extraction stage were each screened for antibacterial activity tests against $E$. coli and $B$. subtilis bacteria. Bioactivity test results in bacteria $E$. coli and $B$. subtilis were observed based on the diameter of inhibition zones, as tabulated in Table 1. 
Table 1. The results of inhibitory zone of the extracts (in $\mathrm{mm}$ ) against E. coli and B. subtilis.

\begin{tabular}{|l|c|c|c|c|c|c|}
\hline & \multicolumn{3}{|c|}{ E. coli } & \multicolumn{3}{c|}{ B. subtilis } \\
\hline Concentration & n-hexane & EtOAc & MeOH & n-hexane & EtOAc & MeOH \\
\hline $0.3 \mathrm{mg} /$ disc & - & 10 & 8 & - & 8 & 7 \\
$0.5 \mathrm{mg} /$ disc & - & 11 & 9 & - & 9 & 8 \\
\hline
\end{tabular}

The results of the antibacterial screening test on the three extracts by diffusion method showed that EtOAc extract exhibited better bioactivity, compared to n-hexane and methanol extracts. Furthermore, the repetition of the antibacterial activity test carried out using a dilution method in order to determine the minimum inhibitory concentration (MIC) of each fraction. The results of the MIC test of the three extracts using the dilution method against $E$. coli and $B$. subtilis bacteria can be seen in Figure 3 , while the optical density (OD) values can be seen in Table 2.

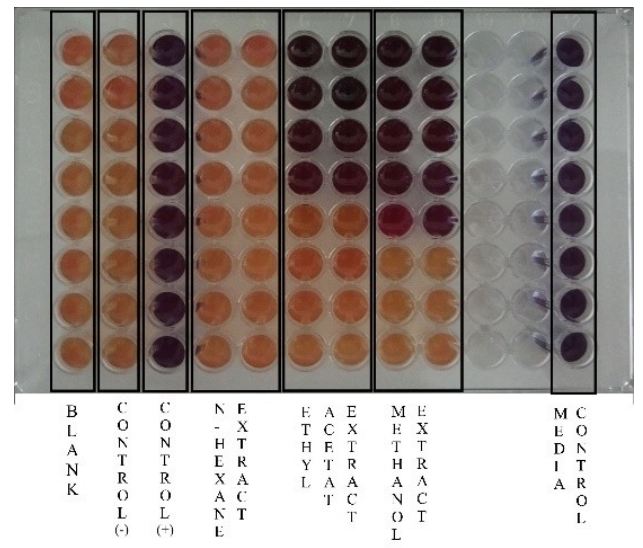

(a)

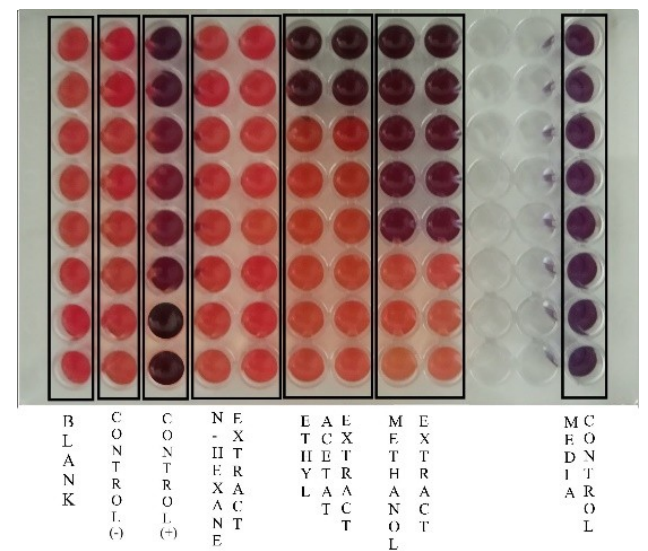

(b)

Figure 3. MIC testing of n-hexane, EtOAc, and methanol extracts using 96-well plates (a) on $E$. coli (b) bacteria on $B$. subtilis bacteria.

Table 2. The results of MIC test of $n$-hexane, EtOAc, and methanol extract using dilution method against $E$. coli and $B$. Subtilis.

\begin{tabular}{|c|c|c|c|c|c|}
\hline No & $\begin{array}{l}\text { Type of } \\
\text { extract }\end{array}$ & $\begin{array}{l}\text { Average } \\
\text { of OD on } \\
E . \text { coli* }^{*}\end{array}$ & $\begin{array}{l}\text { Average } \\
\text { of OD on } \\
\text { B. } \\
\text { subtilis* }\end{array}$ & $\begin{array}{l}\text { MIC }(\mu g / m L) \\
\text { on E. coli }\end{array}$ & $\begin{array}{l}\text { MIC }(\mu \mathrm{g} / \mathrm{mL}) \\
\text { on B. subtilis }\end{array}$ \\
\hline 1 & n-hexane & 0.76838 & 0.54231 & - & - \\
\hline 2 & EtOAc & 1.88706 & 1.48556 & 12.5 & 50 \\
\hline 3 & Methanol & 1.68644 & 1.66288 & 6.25 & 6.25 \\
\hline 4 & Positive control & 1.773 & 1.48025 & 0.78 & 0.78 \\
\hline 5 & $\begin{array}{l}\text { Negative } \\
\text { control }\end{array}$ & 0.74013 & 0.57575 & - & - \\
\hline
\end{tabular}

The test results based on Table 2 show that semipolar EtOAc extract and polar methanol demonstrate a minimum inhibitory concentration better than $n$-hexane extract. In this dilution antibacterial test, using visual observation is not sufficient to observe the presence or absence of bacterial growth; however, this tends to be subjective from each person's eyesight so the risk of error is relatively greater. This occurs because the color test makes it difficult to observe, so absorbance values before and after incubation are used to help determine the presence or absence of bacteria. The wavelength used to measure the number of microbes is $600 \mathrm{~nm}$, because cells in the mitochondria and cytoplasm absorb at that wavelength (28). After incubation for 18 hours and 
measuring the $O D$, the addition of the reaction color was resazurin and was reincubated for 4 hours until the color changed. This color change occurred because resazurin exhibits a blue color that is not fluorescent, and it can be reduced to a fluorescent pink color. The change in color from blue to pink is an indicator of cell reduction. The color change of resazurin is carried out by enzymes in cells in the mitochondria and cytoplasm (27).

Based on the results of the antibacterial tests that were carried out, EtOAc extract was chosen for the fractionation and purification process because it exhibits the best antibacterial activity in inhibiting bacterial growth to a minimum inhibitory concentration of 12.5 and $50 \mu \mathrm{g} / \mathrm{mL}$, compared to extract $n$-hexane, which demonstrates no inhibition at all. The results of fractionation with the VLC process showed that a separation was present between semi-polar components and non-polar components, resulting in seven combined fractions, namely $E_{2} 1$ (fr.1-10; 23 mg), $E_{2} 2$ (fr.11; $439.5 \mathrm{mg}$ ), $E_{2} 3$ (fr.12; 1,336 mg), $E_{2} 4$ (fr.13), $E_{2} 5$ (fr.14-15), $E_{2} 6$ (fr.16-19), $E_{2} 7$ (fr.20-23; 1,675 mg). All these fractions were screened for antibacterial activity using the agar diffusion method, and the results obtained were tabulated in Table 3. B. subtilis

Table 3. The diameter of inhibition zone $(\mathrm{mm})$ of VLC-1 and VLC-2 fractions against E.coli and

\begin{tabular}{lcccccccc}
\hline & \multicolumn{3}{c}{ E. coli } & \multicolumn{5}{c}{ B. subtilis } \\
\hline Concentration & $\mathbf{E}_{\mathbf{2}} \mathbf{1}$ & $\mathbf{E}_{\mathbf{2}} \mathbf{2}$ & $\mathbf{E}_{\mathbf{2}} \mathbf{3}$ & $\mathbf{E}_{\mathbf{2}} \mathbf{7}$ & $\mathbf{E}_{\mathbf{2}} \mathbf{1}$ & $\mathbf{E}_{\mathbf{2}} \mathbf{2}$ & $\mathbf{E}_{\mathbf{2}} \mathbf{3}$ & $\mathbf{E}_{\mathbf{2}} \mathbf{7}$ \\
\hline $0.3 \mathrm{mg} /$ disk & 7 & 10 & 8 & 7 & 7 & 10 & 8 & 7 \\
$0.5 \mathrm{mg} /$ disk & 7 & 11 & 8 & 8 & 7 & 12 & 9 & 8
\end{tabular}

Using a dilution method to determine the MIC value, each antibacterial active fraction obtained above was then re-tested for bioactivity. The results of the
MIC test can be seen in Figure 4, and the average OD of each fraction can be seen in Table 4.

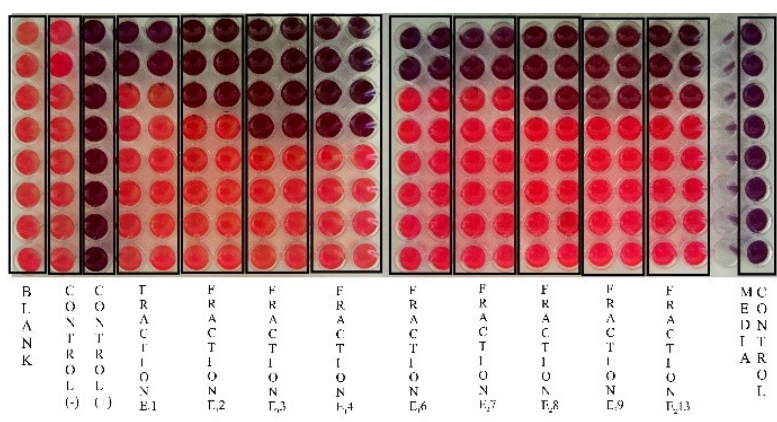

(a)

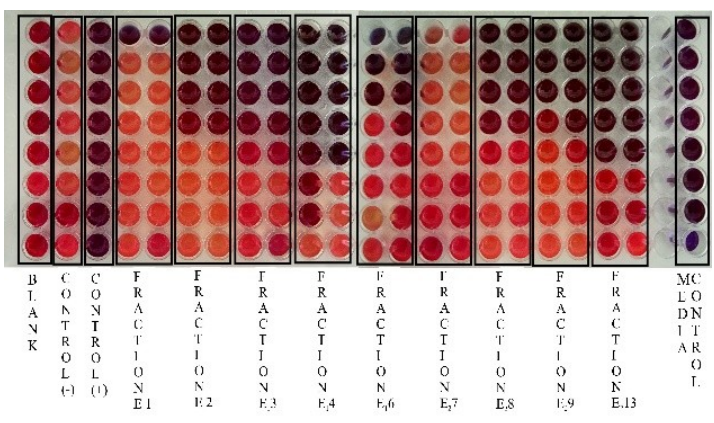

(b)

Figure 4. The MIC test on VLC fractions against: (a) E. coli; (b) B. subtilis.

Table 4. The result of MIC test of VLC fraction against $E$. coli and $B$. subtilis using dilution method.

\begin{tabular}{|c|c|c|c|c|c|}
\hline No & $\begin{array}{l}\text { Fraction } \\
\text { code }\end{array}$ & $\begin{array}{l}\text { OD } \\
\text { average } \\
\text { on E. coli }\end{array}$ & $\begin{array}{l}\text { OD average } \\
\text { on } \quad B . \\
\text { subtilis }\end{array}$ & $\begin{array}{l}\text { MIC }(\mu \mathrm{g} / \mathrm{mL}) \\
\text { on } E . \text { coli }\end{array}$ & $\begin{array}{c}\text { MIC }(\mu \mathrm{g} / \mathrm{mL}) \\
\text { subtilis }\end{array}$ \\
\hline 1 & $E_{2} 1$ & 1.16363 & 1.02819 & 50 & - \\
\hline 2 & $E_{2} 2$ & 1.49338 & 1.54488 & 25 & 25 \\
\hline 3 & $E_{2} 3$ & 1.25269 & 1.74956 & 25 & 25 \\
\hline 4 & $E_{2} 7$ & 1.39525 & 2.34931 & 25 & 6,25 \\
\hline 5 & $\begin{array}{l}\text { Positive } \\
\text { control }\end{array}$ & 2.16563 & 2.28425 & 0,78 & 0,78 \\
\hline 6 & $\begin{array}{l}\text { Negative } \\
\text { control }\end{array}$ & 0.86413 & 0.60838 & - & - \\
\hline
\end{tabular}


From the test results shown in Table 4, it was found that the fractions of $E_{2} 2, E_{2} 3$, and $E_{2} 7$ gave a smaller value of the minimum inhibitory concentration compared to other fractions both against $E$. coli and B. subtilis bacteria. The $\mathrm{E}_{2} 2$ fraction $(439.5 \mathrm{mg})$ was then selected for further purification by mass consideration. Phytochemical screening, especially flavonoid and phenolic tests, was carried out on the $\mathrm{E}_{2} 8$ fraction, which showed positive tests for the presence of flavonoids and phenolics. Purification of the $E_{2} 2$ fraction $(439.5 \mathrm{mg})$ produced six main subfractions, namely $E_{2} 2 a(132.0 \mathrm{mg}), E_{2} 2 b(8.4$ $\mathrm{mg}), E_{2} 2 \mathrm{c}(9.0 \mathrm{mg}), E_{2} 2 \mathrm{~d}(47.0 \mathrm{mg}), E_{2} 2 \mathrm{e}(2.0 \mathrm{mg})$, and $E_{2} 2 f(50.3 \mathrm{mg}$ ). Then, the subfractions were carried out using MIC test 96-well plates, to determine the minimum inhibitory concentration of the subfraction. The results of MIC on E. coli bacteria are that the $E_{2} 2 c, E_{2} 2 d, E_{2} 2 e$, and $E_{2} 2 f$ fractions exhibit a better minimum inhibitory concentration compared to other fractions. However, the MIC results in $B$. subtilis bacteria all fractions showed lower inhibitory ability than in $E$. coli bacteria. The results of the $E_{2} 2$ subfraction $M I C$ can be seen in Figure 5 and for the average OD of each fraction can be seen in Table 5 .

Table 5. The result of MIC test on $\mathrm{E}_{2} 8_{1}$ subfraction using 96 -well plates against $E$. coli and $B$. subtilis

\begin{tabular}{|c|c|c|c|c|c|}
\hline No & $\begin{array}{l}\text { Subfraction } \\
\text { code }\end{array}$ & $\begin{array}{c}\text { Average } \\
\text { of OD on } \\
\text { E. coli }\end{array}$ & $\begin{array}{c}\text { Average of } \\
\text { OD on } B \text {. } \\
\text { subtilis }\end{array}$ & $\begin{array}{c}\text { MIC }(\mu \mathrm{g} / \mathrm{mL}) \text { in } \\
\text { E. coli }\end{array}$ & $\begin{array}{l}\text { MIC }(\mu \mathrm{g} / \mathrm{mL}) \\
\text { in B. subtilis }\end{array}$ \\
\hline 1 & $E_{2} 2 a$ & 1.49731 & 1.27825 & 50 & 100 \\
\hline 2 & $E_{2} 2 b$ & 1.44425 & 1.22788 & 50 & 50 \\
\hline 3 & $E_{2} 2 c$ & 1.29094 & 0.99919 & 25 & 50 \\
\hline 4 & $E_{2} 2 d$ & 1.25900 & 0.84613 & 25 & 50 \\
\hline 5 & $E_{2} 2 e$ & 1.39463 & 1.18294 & 12,5 & 25 \\
\hline 6 & $E_{2} 2 f$ & 1.34638 & 1.14100 & 25 & 25 \\
\hline 7 & $\begin{array}{l}\text { Positive } \\
\text { control }\end{array}$ & 1.54525 & 1.45938 & 0,78 & 0,78 \\
\hline 8 & $\begin{array}{c}\text { Negative } \\
\text { control }\end{array}$ & 0.85238 & 0.56950 & 0 & 0 \\
\hline
\end{tabular}

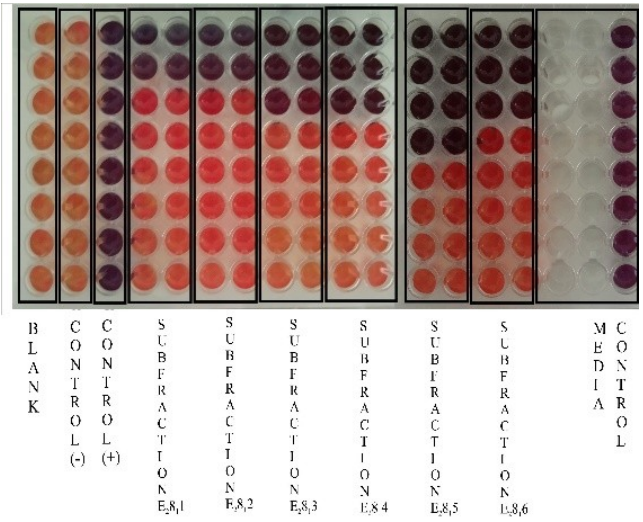

(a)

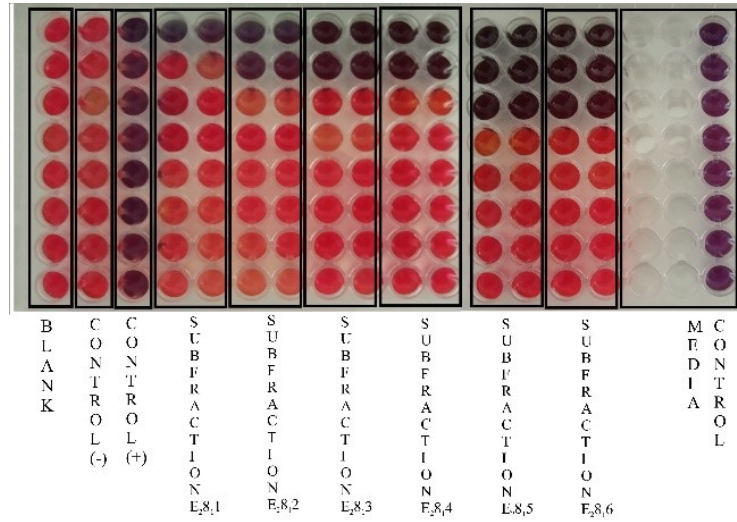

(b)

Figure 5. MIC test on $\mathrm{E}_{2} 2$ subfractions using 96-well plates against: (a) E. coli; (b) B. subtilis.

Based on the results obtained, a decrease in the minimum inhibitory concentration can be seen compared to the antibacterial activity test on the VLC results as observed on the purification results of the $E_{2} 2$ fraction. This fact occurs due to the possible composition of active compounds contained in the sample. According to Priya et al. (29), when an increase or decrease in a component of an active compound occurs, a possibility of influencing the activeness of the compound itself exists. From the test results shown in Table 5, researchers found that the $E_{2} 2 e$ and $E_{2} 2 f$ subfractions gave a smaller minimum inhibitory concentration value compared to other subfractions, both against $E$. coli and $B$. subtilis bacteria. Among them, two subfractions $\left(E_{2} 2 e\right.$ and $\left.E_{2} 2 f\right)$ performed the most antibacterial activity against $B$. subtilis and $E$. coli, with the MIC's values ranging from $12.5-25 \mu \mathrm{g} / \mathrm{mL}$.

However, $E_{2} 2 f$ was chosen to be further characterized because in terms of quantity more than $E_{2} 2 e$. As can be seen in Figure 6, subsequent 
characterization of the $E_{2} 2 f$ subfraction was carried out using proton nuclear magnetic spectroscopy $\left({ }^{1} \mathrm{H}\right.$ NMR).

The spectrum shown in Figure 6 indicates that the $E_{2} 2 f$ subfraction is not pure. However, interpretation of the ${ }^{1} \mathrm{H}-\mathrm{NMR}$ data can still be done, by referring to the results of the phytochemical test of the fraction which shows the content of phenolic compounds or flavonoids in the subfraction. Therefore, a comparison reporting the presence of phenolic or flavonoid compounds in the same plant type is sought in journals to estimate the types of bioactive compounds which are obtained. From the NMR spectrum of proton $E_{2} 2 f$ subfraction, the results show indications of aromatic protons in the chemical shift region $\delta_{H} 6-7$. The signal for the methoxy group $\left(-\mathrm{OCH}_{3}\right)$ at $\delta_{\mathrm{H}} 3.7$, the proton signal at $\delta_{\mathrm{H}} 8.01$ with the peak of the chemical shift of the hydroxyl group $(-\mathrm{OH})$ attached to an aromatic ring. As well as the typical peaks for alkanes at $\delta_{H}$ 0.89-2.2.

The isolation of phenolic compounds from the fruit skin of jengkol plants, and the researchers identified them as 1-(2,6-dihydroxy-4-methoxyphenyl) decan1-one (Figure 7) has previously been reported (30). Based on the comparison of the proton chemical shift values between the isolated subfraction and 1(2,6-dihydroxy-4-methoxyphenyl) decan-1-one, researchers estimated that the main active compound contained in the $E_{2} 2 f$ subfraction is a phenolic compound, namely 1-(2, 6-dihydroxy-4methoxyphenyl) decan-1-one. However, further purification in the $E_{2} 2 f$ subfraction still needs to be performed, to ensure the active compounds which are responsible for inhibition of the test bacteria. The results obtained in the spectrum exhibit similarities with the spectrum that was reported by others (30), as can be seen in Table 6. However, antibacterial studies have not yet been found against compound 1-(2,6-dihydroxy-4methoxyphenyl) decan-1-one, so it is thought to be synergistic: between compounds 1-(2,6-dihydroxy-4methoxyphenyl) decan-1-one with other compounds that cause antibacterial activity, as seen in the antibacterial test results in fractions of VLC results.

Table 6. Comparison of chemical shifts in ${ }^{1} \mathrm{H}-\mathrm{NMR}$ subfraction $\mathrm{E}_{2} 2 \mathrm{f}$ with compounds 1-(2,6-dihydroxy-4methoxyphenyl)decan-1-one.

\begin{tabular}{|l|l|c|c|}
\hline No & Proton type & $\boldsymbol{\delta}_{\mathbf{H}}$ proton in Subfraction $\mathbf{E}_{\mathbf{2}} \mathbf{8}_{\mathbf{1}} \mathbf{6} \mathbf{( \mathbf { p p m } )}$ & $\begin{array}{c}\mathbf{\delta}_{\mathbf{H}} \text { Proton in reference compound } \\
\mathbf{( 3 0 )}\end{array}$ \\
\hline $\mathbf{1}$ & Aromatic & $6-7$ & 7.04 \\
\hline $\mathbf{2}$ & Methoxy & 3.7 & 3.79 \\
\hline $\mathbf{3}$ & Hydroxy Aromatic & 8.01 & 8.01 \\
\hline $\mathbf{4}$ & Alkane & $0.89-2.2$ & $0.89-2.21$ \\
\hline
\end{tabular}

Based on the results of interpretation of ${ }^{1} \mathrm{H}-\mathrm{NMR}$, data seen in Table 7 indicate that the $E_{2} 2$ subfraction is not pure, but it is seen in the integration that indicates the possibility of the presence of three mixed compounds distributed in the chemical shift region $\delta_{H}$ 0.89-8.01 ppm. The first group exhibits chemical shifts that are distributed in the area of $\delta_{H} 8.01,6.8,6.79,6.76,6.74,6.20,5.87$, $4.58,3.99,2.53$, and $1.67 \mathrm{ppm}$. The second group is distributed in the area of chemical shift $\delta_{H} 7.05$, $6.82,5.91$, and $4.20 \mathrm{ppm}$. Whereas, the third group was distributed in the area of chemical shift $\delta_{H} 6.36$, 6.29 , and $0.89 \mathrm{ppm}$. The complete shift of proton chemistry and its integration can be seen in Table 7.

Table 7. Coupling constant and ${ }^{1} \mathrm{H}-\mathrm{NMR}$ Integration of $\mathrm{E}_{2} 2 \mathrm{f}$ subfraction.

\begin{tabular}{llccc}
\hline No & $\begin{array}{l}\boldsymbol{\delta}_{\mathbf{H}} \\
(\mathbf{p p m})\end{array}$ & Multiplicity & Integration & J (Hz) \\
\hline 1 & 8.01 & $d$ & $0.90^{1}$ & 16.5 \\
2 & 7.05 & $d$ & $0.26^{2}$ & 2.5 \\
3 & 6.8 & $d$ & $0.91^{1}$ & 2.5 \\
4 & 6.82 & $d$ & $0.69^{2}$ & 1.5 \\
5 & 6.79 & $m$ & $1.23^{1}$ & 4 \\
6 & 6.76 & $d$ & $2.23^{1}$ & 1.5 \\
7 & 6.74 & $d$ & $2.23^{1}$ & 1.5 \\
8 & 6.36 & $d$ & $0.33^{3}$ & 2.5 \\
9 & 6.29 & $d$ & $0.31^{3}$ & 2.5 \\
10 & 6.20 & $m$ & $2.50^{1}$ & 2.5 \\
9 & 5.91 & $m$ & $0.42^{2}$ & 2.5 \\
10 & 5.87 & $m$ & $2.00^{1}$ & 2 \\
13 & 4.58 & $m$ & $2.40^{1}$ & 7.5 \\
14 & 4.20 & $t$ & $0.45^{2}$ & 4 \\
15 & 3.70 & $m$ & $3.21^{1}$ & 3 \\
16 & 2.53 & $m$ & $2.10^{1}$ & 3.5 \\
17 & 1.67 & $m$ & $1.24^{1}$ & 5.5 \\
18 & 0.89 & $m$ & $0.58^{3}$ & 8.5 \\
\hline
\end{tabular}

Superscripted 1, 2, and 3 are codes for different types of groups of compounds. 
Noviany et al. JOTCSA. 2021; 8(2): 391-402.

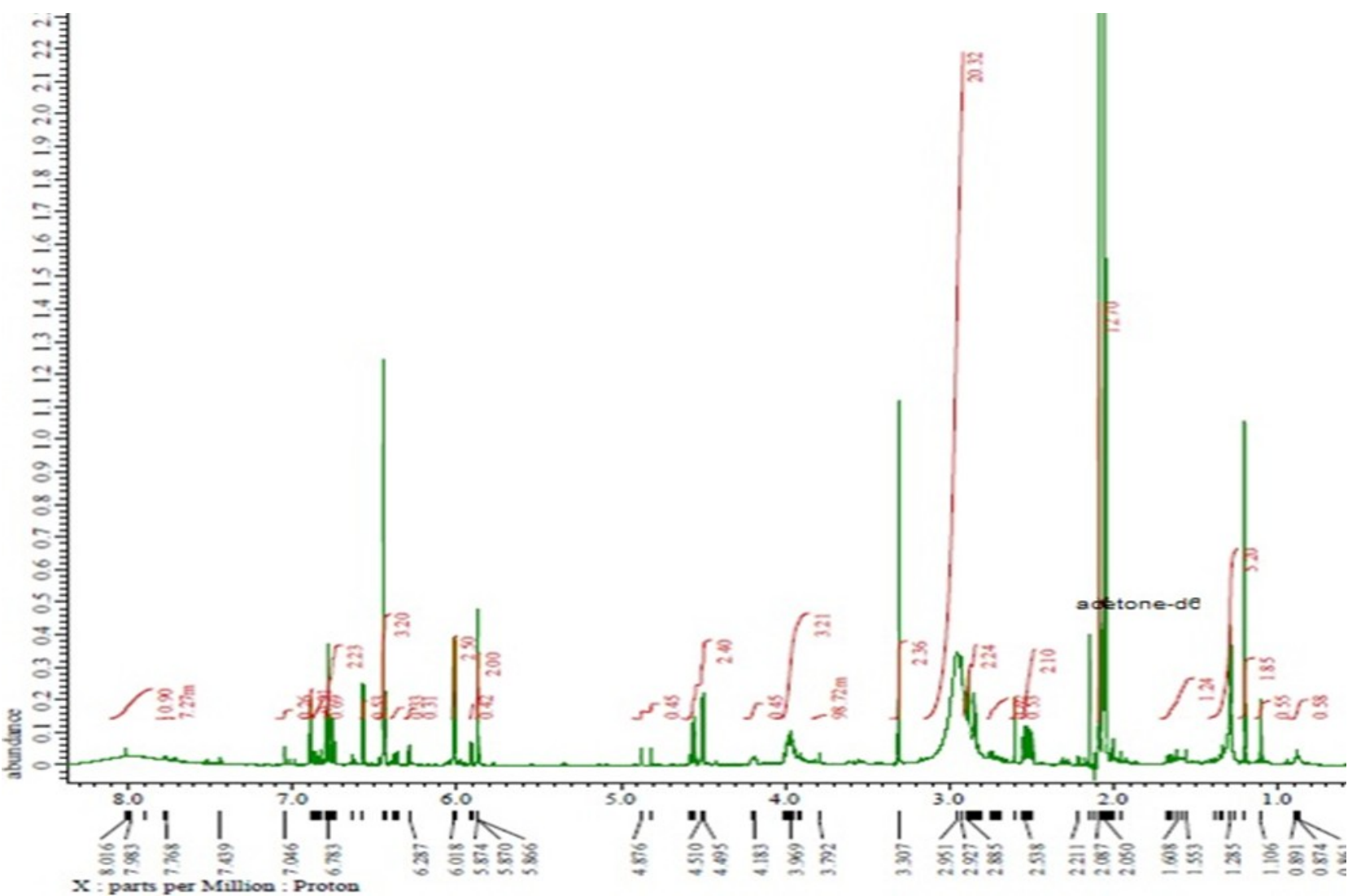

(a)

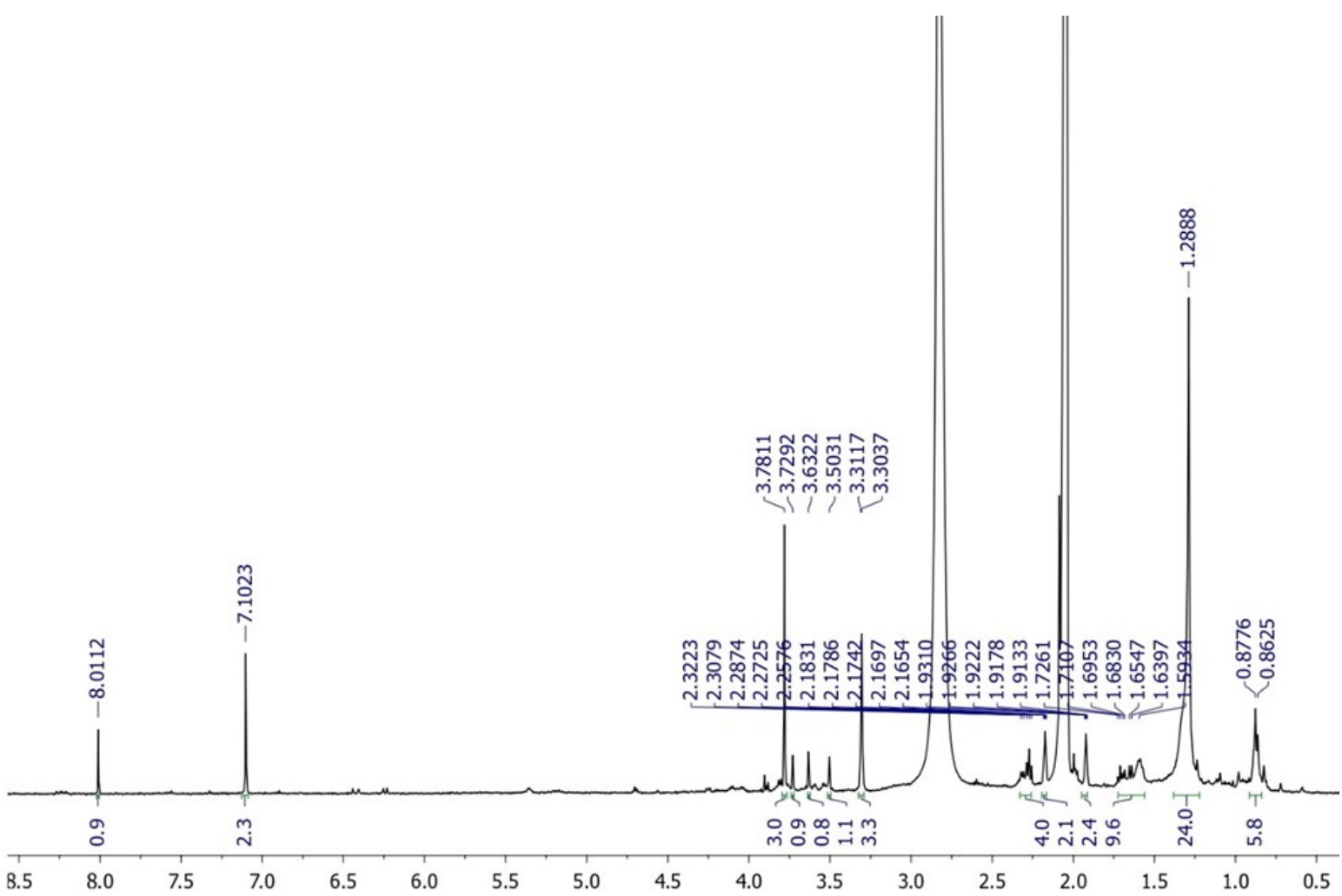

(b)

Figure 6. ${ }^{1} \mathrm{H}-\mathrm{NMR}$ spectra of (a) $\mathrm{E}_{2} 2 \mathrm{f}$ subfraction; (b) Reference compound (30). 
<smiles>CCCCCCCCCC(=O)c1c(O)cc(OC)cc1O</smiles>

Figure 7. Structure of compound 1- (2,6-dihydroxy-4-methoxyphenyl) decan-1-one.

\section{CONCLUSIONS}

The EtOAc extract of jengkol ( $A$. jiringa (Jack) I. C. Nielsen) root bark exhibits antibacterial activity against $E$. coli and $B$. subtilis bacteria, which is better than the $n$-hexane extract. Compared to other fractions from the same column, the E13 fraction and E28 fraction exhibit better antibacterial activity against $E$. coli and $B$. subtilis bacteria. The E13 fraction and E28 fraction exhibit better antibacterial activity against $E$. coli and $B$. subtilis, compared to the E13 subfraction and E28 fraction as a result of its purification. Based on the ${ }^{1} \mathrm{H}-\mathrm{NMR}$ result data, the compounds detected in the $E_{2} 8_{1} 6$ subfraction are a phenolic compound type. Lastly, this study is the first reported from this plant and the potential exists to further investigate the invention of new promising antibacterial agent from plants.

\section{ACKNOWLEDGMENTS}

The authors would like to thank to the Institute of Research and Community Services, Universitas Lampung that provided fund for this project to be undertaken through Penelitian Kerjasama Internasional/International Research Collaboration 2019 (No.3093/UN26.21/PN/2019). The authors would like to thank Enago (www.enago.com) for the English language proofread and review. We also gratefully acknowledge UPT LTSIT of the University of Lampung for technical assistance.

\section{CONFLICTS OF INTEREST}

The authors declare no conflicts of interest.

\section{REFERENCES}

1. Van TTH, Nguyen HNK, Smooker PJ, Coloe PJ. The antibiotic resistance characteristics of nontyphoidal Salmonella enterica isolated from foodproducing animals, retail meat and humans in South East Asia. Int. J. Food Microbiol. 2012; 154: 98-106.

2. Sulaiman M, Hassan Y, Taskin-Tok T, Noundou XS. Synthesis, Antibacterial Activity and Docking Studies Of Benzyl Alcohol Derivatives. J. Turk. Chem. Soc.

Sect. A: Chem. 2020; 7(2): 481-8.

3. World Health Organization. WHO Global Strategy for Containment of Antimicrobial Resistance. World Health Organization. 2001; 53-5.

4. Oyofo BA, Lesmana $M$, Subekti D, Tjaniadi $P$, Larasati W, Putri M, Simanjuntak $\mathrm{CH}$, Punjabi NH, Santoso W, Muzahar, Sukarma, Sriwati, Sarumpaet S, Abdi M, Tjindi R, Ma'ani H, Sumardiati A,
Handayani H, Campbell JR, Alexander WA, Beecham III HJ, Corwin AL. Surveillance of bacterial pathogens of diarrhea disease in Indonesia. Diagn. Mic. Infec. Dis, 2002; 44: 227-34.

5. Annissa, Suhartati T, Yandri, Hadi S. Antibacterial Activity of Diphenyltin(IV) and Triphenyltin(IV) 3Chlorobenzoate againts Pseudomonas aeruginosa and Bacillus subtilis. Orient. J. Chem. 2017; 33: 1133-9.

6. Hadi S, Hermawati E, Noviany, Suhartati T, Yandri. Antibacterial Activity Test of DiphenyltinIV) Dibenzoate and Triphenyltin(IV) Benzoate Compounds against Bacillus substilis and Pseudomonas aeruginosa. Asian J. Microbiol. Biotech. Env. Sci. 2018; 20; 113-9.

7. Bischoff KM, White DG, Mcdermott PF, Zhao S, Gaines S, Maurer JJ. Characterization of Chloramphenicol Resistance in BetaHemolytic Escherichia coli Associated with Diarrhea in Neonatal Swine. J. Clin. Microbiol. 2002; 40: 389-94.

8. Bischoff KM, White DG, Hume ME, Poole TL, Nisbet DJ. The chloramphenicol resistance gene $\mathrm{cm} / \mathrm{A}$ is disseminated on transferable plasmids that confer multiple-drug resistance in swine Escherichia coli. FEMS Microbiol. Lett. 2005; 243: 285-91.

9. Stapleton P, Wu PJ, King A, Shannon K, French $G$, Phillips I. Incidence and mechanisms of resistance to the combination of amoxicillin and clavulanic acid in Escherichia coli. Antimicrob. Agents Chemother. 1995; 39: 2478-83.

10. Küçük $S$, Soyer $P$, Tunali Y. Determination of Antimicrobial and Biological Activities of Salvia sclarea L. (Lamiaceae) Extracts. J. Turk. Chem. Soc. Sect. A: Chem. 2019; 6 (1): 15-20.

11. Noviany N, Samadi A, Carpenter EL, Abugrain ME, Hadi S, Purwitasari N, Indra G, Indra A, Mahmud $T$. Structural revision of sesbagrandiflorains $A$ and $B$, and synthesis and biological evaluation of 6methoxy-2-arylbenzofuran derivatives. J. Nat. Med. 2020; August (online first).

12. Noviany N, Osman H, Mohamad S, Hadi S. Antibacterial activity of extracts and compounds from the roots of Sesbania grandiflora

(Leguminosae). Res. J. Chem. Environ. 2020; 24(8): 108-13. 
13. Hadi S, Noviany. The Isolation of Hopeaphenol, a Tetramer Stilbene, from Shorea ovalis Blume. Adv. Nat. Appl. Sci. 2009; 3(1): 107-12.

14. Suhartati T, Yandri, Suwandi JF, Hadi S. In vitro and in vivo antiplasmodial activity of oxyresveratrol and artonine isolated from two Artocarpus plants in Indonesia. Orient. J. Chem. 2010; 26(3): 825-30.

15. Noviany N, Nurhidayat A, Hadi S, Suhartati T, Aziz M, Purwitasari N, Subasman I.

Sesbagrandiflorain A and B: isolation of two new 2arylbenzofurans from the stem bark of Sesbania grandiflora. Nat. Prod. Res. 2018; 32(21): 2558-64.

16. Suhartati T, Epriyanti E, Borisha I, Yandri, Suwandi JF, Yuwono SD, Qudus HI, Hadi S. In Vivo Antimalarial Test of Artocarpin and in vitro Antimalarial Test of Artonin M Isolated from Artocarpus. Rev. Chim. 2020; 71(5): 400-8.

17. Noviany N, Samadi A, Yuliyan N, Hadi S, Aziz M, Purwitasari N, Mohamad S, Ismail NN, Gable KP, Mahmud T. Structure characterization and biological activity of 2-arylbenzofurans from an Indonesian plant, Sesbania grandiflora (L.) Pers. Phytochem. Lett. 2020; 35: 211-5.

18. Lim TK. Archidendron jiringa. In: Edible Medicinal and Non-Medicinal Plants. Springer, Dordrecht. 2012; 835 p.

19. Charungchitrak S, Petsom A, Sangvanich $P$, Karnchanatat A. Antifungal and antibacterial activities of lectin from the seeds of Archidendron jiringa Nielsen. Food Chem. 2011; 126: 1025-32.

20. Hasan N, Osman H, Mohamad S, Chong WK, Awang K, Zahariluddin ASM. The Chemical Components of Sesbania grandiflora Root and Their Antituberculosis Activity. Pharmaceuticals. 2012; 5: 882-9.

21. Lubis MY, Siburian R, Marpaung L, Simanjuntak P, Nasution MP. Methyl Gallate from Jiringa (Archidendron Jiringa) and Antioxidant Activity. Asian J. Pharm. Clin. Res, 2018; 11: 346-50.
22. Laladhas KP, Cheriyan VT, Puliappadamba VT, Bava SV, Unnithan RG, Vijayammal PL, Anto RJ. A novel protein fraction from Sesbania grandiflora shows potential anticancer and chemopreventive efficacy, in vitro and in vivo. J. Cell Mol. Med. 2010;14: 636-46.

23. Gbeassor. M, Kedjagni AY, Koumaglo K, De Souza C, Agbo K, Aklikokou K, Amegbo KA. In vitro antimalarial activity of six medicinal plants. Phytother. Res. 1990; 4: 115-7.

24. Bunawan $H$, Dusik L, Bunawan SN, Amin NM. Botany, Traditional Uses, Phytochemistry and Pharmacology of Archidendron jiringa: A Review. Global J. Pharmacol. 2013; 7: 474-8.

25. Gul R, Jan SU, Faridullah S, Sherani S, Jahan N. Preliminary Phytochemical Screening, Quantitative Analysis of Alkaloids, and Antioxidant Activity of Crude Plant Extracts from Ephedra intermedia Indigenous to Balochistan. Sci. World. J. 2017; Article ID 5873648.

26. Bauer AW, Kirby WMM, Sheriss JC, Turck M. Antibiotic susceptibility testing by a standardized single disk method. Am. J. Clin. Pathol. 1966; 45(4): 493-6.

27. Sarker SD, Nahar L, Kumarasamy Y. Microtitre plate-based antibacterial assay incorporating resazurin as an indicator of cell growth, and its application in the in vitro antibacterial screening of phytochemicals. Methods, 2007; 42: 321-4.

28. Begot C, Desnier I, Daudin JD, Labadie JC, Lebert A. Recommendations for calculating growth parameters by optical density measurements. J. Microbiol. Meth. 1996; 25: 225-32.

29. Priya V, Mallika J, Surapaneni KM, Saraswathi $P$, Chandra SG. Antimicrobacterial Activity of Pericarp Exstract of Garcinia mangostana Linn. Int. J. Pharm. Sci. Res. 2010; 8: 278-81.

30. Sopian A, Darmawan A, Simanjuntak P. Identification of phenolic compounds in Ethylacetate extract of Jengkol skin fruit. Ej. Poltektegal. 2019; 8: 51-5. (in Indonesian). 
